\title{
NOTE ON THE SPECTRUM OF NOVA PERSEI
}

Spectrograms of Nova Persei were secured at intervals during the fall and winter, up to January int 7 th. The spectrum remained, without appreciable , change, as described by us in Bulletin No. 8. In , int that publication attention was called to the presence

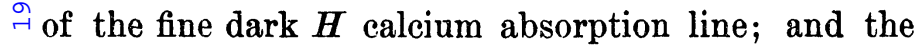
opinion was ventured that perhaps the corresponding $K$ line was "absent only by reason of the fact that there the calcium vapor has nothing to absorb." To test this point, Mr. Wright made a long exposure, sufficient to record the continuous spectrum in the $\boldsymbol{H}$ and $K$ region. The fine dark $K$ line is present.

In this connection it would be exceedingly interesting to know whether the absorption lines of calcium, sodium and other elements would be detected in the spectra of well-known gaseous nebulae, - the exposures being long enough to record the continuous portions of their spectra.

W. W. Campbell.

W. H. WRIGHT.

\section{O. MILLS EXPEDITION TO THE SOUTHERN HEMISPHERE}

The 37t-inch Cassegrain reflecting-telescope mirror, to be used by the Mills Expedition in determining the radial velocities of the brighter stars south of $-30^{\circ}$ declination, was completed by the John A. Brashear Company on June 20th. The $9 \frac{3}{4}$-inch convex secondary mirror has likewise been completed. Both are en route to Mt. Hamilton. The telescope mounting, designed in general plan by the Director, and in detail by the builders, Harron, Rickard and McCone of San Francisco, has for several months been set up for trial in the rear of the Observatory buildings. A three-prism spectrograph, designed by the Director, optical parts by Brashear and mounting by our instrument-maker, has been completed and tested. A modern steel dome, 30 feet in diameter, has been constructed by The Warner \& Swasey Company. It is hoped that the Expedition may be able to sail in the near future for Valparaiso, to occupy a station near Santiago, Chile.

July $1,1902$.
W. W. Campbell.

\section{A LIST OF SIX STARS WHOSE VELOCITIES IN THE LINE OF SIGHT ARE VARIABLE}

The following six spectroscopic binaries, discovered with the Mills spectrograph, are additional to the thirty-two binaries already announced:

$$
\phi \text { Persei }\left(\alpha=1^{\mathrm{h}} 37^{\mathrm{m}} ; \delta=+50^{\circ} 11^{\prime}\right) .
$$

The variable velocity of this star was discovered from the second plate. The observations are:

\begin{tabular}{|c|c|c|c|c|}
\hline 1898 & $\begin{array}{l}\text { Date. } \\
\text { September }\end{array}$ & 5 & $\begin{array}{l}\text { Velocity. } \\
-2^{\mathrm{km}}\end{array}$ & $\begin{array}{c}\text { Measured by } \\
\text { Reese }\end{array}$ \\
\hline 1900 & $\begin{array}{c}\text { December } \\
"\end{array}$ & & $\begin{array}{l}+24 \\
+23\end{array}$ & $\begin{array}{l}\text { Reese } \\
\text { Campbell }\end{array}$ \\
\hline & October & $15 \ldots \ldots \ldots \ldots$ & -10 & Reese \\
\hline & November & $11 .$. & -12 & Reese \\
\hline
\end{tabular}

This star has bright hydrogen lines, its bright $H_{\beta}$ haying been discovered by Espin (Astr. Nach., No. 2963). The $H \gamma$ line may perhaps be best described as a comparatively narrow absorption line with very bright borders. The measures refer to the middle of the dark line. No other lines are apparent in the $H \gamma$ region.

$$
\eta \text { Geminorum }\left(a=6^{\mathrm{h}} 09^{\mathrm{m}} ; \delta=+22^{\circ} 33^{\prime}\right) .
$$

The observations of this star thus far secured are as follows, the variable velocity having been discov-

\begin{tabular}{|c|c|c|c|}
\hline 1900 & $\begin{array}{lr}\text { Date. } & \\
\text { January } & 15 \ldots \ldots \ldots \ldots . . \\
n & \ldots \ldots \ldots \ldots \ldots\end{array}$ & $\begin{array}{l}\text { Velocity. } \\
+15.8^{\mathrm{km}} \\
+14\end{array}$ & $\begin{array}{l}\text { Measured by } \\
\text { Reese } \\
\text { Stebbins }\end{array}$ \\
\hline & January $21 \ldots$. & +15 & Reese \\
\hline 1901 & October 13 . & +22.1 & Rsese \\
\hline & November $6 . .$. & +20.3 & Reese \\
\hline & December $4 \ldots$. & +22.8 & Reese \\
\hline 1902 & $\underset{\mu}{\text { February }} 2 \ldots \ldots \ldots \ldots$ & $\begin{array}{l}+25 \\
+23\end{array}$ & $\begin{array}{l}\text { Reese } \\
\text { Stebbins }\end{array}$ \\
\hline
\end{tabular}
ered from the third plate: 
$\gamma$ CANis Minoris $\left(a=7^{\mathrm{h}} 23^{\mathrm{m}} ; \delta=+9^{\circ} 08^{\prime}\right)$.

The observations of this star are:

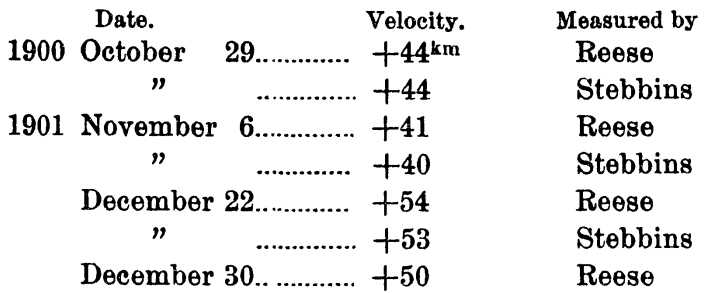

The fourth plate is underexposed.

$\zeta$ HeRculis $\left(\alpha=16^{\mathrm{h}} 38^{\mathrm{m}} ; \delta=+31^{\circ} 47^{\prime}\right)$.

Early observations of the radial velocity of this star were obtained by Belopolsky at Pulkowa, Campbell at Mount Hamilton and Newall at Cambridge, as follows:

\begin{tabular}{|c|c|c|c|c|}
\hline \multirow[t]{7}{*}{1893} & $\begin{array}{l}\text { Date. } \\
\text { May }\end{array}$ & $18 \ldots \ldots \ldots \ldots \ldots$ & $\begin{array}{l}\text { Velocity. } \\
-68^{\mathrm{km}}\end{array}$ & $\begin{array}{l}\text { Measured by } \\
\text { Belopolsky }\end{array}$ \\
\hline & May & $22 \ldots \ldots \ldots \ldots \ldots$ & -84 & Belopolsky \\
\hline & June & $2 \ldots \ldots \ldots \ldots$ & -75 & Belopolsky \\
\hline & June & 3..................... & -67 & Belopolsky \\
\hline & June & $4 \ldots \ldots \ldots \ldots \ldots \ldots$ & -66 & Belopolsky \\
\hline & June & $14 \ldots \ldots \ldots \ldots \ldots$ & -64 & Belopolsky \\
\hline & June & $16 \ldots \ldots \ldots \ldots$ & -69 & Belopolsky \\
\hline \multicolumn{3}{|c|}{ Mean... } & -70.4 & \\
\hline 1897 & April & $29 \ldots \ldots$ & -69.1 & Campbell \\
\hline \multirow[t]{4}{*}{1898} & May & 11.. ................ & -70.4 & Campbell \\
\hline & May & $23 \ldots \ldots \ldots \ldots \ldots$ & -70.0 & Campbell \\
\hline & August & $19 \ldots \ldots \ldots \ldots$ & -70.9 & Campbell \\
\hline & \multicolumn{2}{|c|}{ Mean } & -70.1 & \\
\hline 1897 & June & $14 \ldots \ldots \ldots \ldots \ldots$ & -71.4 & Newall \\
\hline 1898 & May & $16 \ldots \ldots \ldots \ldots$ & -68.4 & Newall \\
\hline 1899 & April & $29 \ldots \ldots \ldots \ldots$ & -74.3 & Newall \\
\hline \multicolumn{3}{|c|}{ Mean } & -71.4 & \\
\hline
\end{tabular}

The above observations afforded no evidence whatever of variable velocity.

Recent observations at the Lick Observatory are as follows:

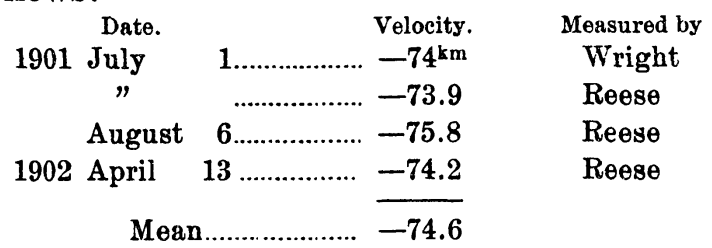

The velocity has therefore changed about $4^{\mathrm{km}}$ since 1898.

This star is a well known visual binary, period about 33 years. $a$ EquUlei $\left(a=21^{\mathrm{h}} 11^{\mathrm{m}} ; \delta=+4^{\circ} 50^{\prime}\right)$.

The variable velocity of this star was detected from the third of the following observations:

\begin{tabular}{|c|c|c|c|c|}
\hline 1900 & $\begin{array}{l}\text { Date. } \\
\text { June }\end{array}$ & $25 \ldots$ & $\begin{array}{l}\text { Velocity. } \\
-26^{\mathbf{k m}}\end{array}$ & $\begin{array}{l}\text { Measured by } \\
\text { Wright }\end{array}$ \\
\hline & July & $18 \ldots \ldots \ldots \ldots$ & -22 & Wright \\
\hline 1901 & June & $25 \ldots \ldots \ldots$ & -2 & Wright \\
\hline & September & $1 \ldots \ldots$ & -14 & Wright \\
\hline & October & $15 \ldots \ldots$ & -12 & Reese \\
\hline 1902 & June & $2 \ldots \ldots$ & -26 & Stebbins \\
\hline
\end{tabular}

This star has a composite spectrum, discovered by Miss Maury of Harvard College Observatory.

o ANDRomedae $\left(a=22^{\mathrm{h}} 57^{\mathrm{m}} ; \delta=+41^{\circ} 47^{\prime}\right)$.

The following observations of this star have been secured:

\begin{tabular}{|c|c|c|c|c|}
\hline \multirow[t]{3}{*}{1900} & $\begin{array}{c}\text { Date. } \\
\text { October }\end{array}$ & 9 & $\begin{array}{r}\text { Velocity. } \\
-11^{\mathrm{km}}\end{array}$ & $\begin{array}{l}\text { Measured by } \\
\text { Wright }\end{array}$ \\
\hline & December & 17 & -15 & Campbell \\
\hline & $"$ & & -17 & Wright \\
\hline & June & 25 & ......... -20 & Wright \\
\hline & August & 12 & ........... -12 & Reese \\
\hline
\end{tabular}

These measures depend entirely upon the excellent $H \gamma$ line.

This star has a composite spectrum, discovered likewise by Miss Maury.

Before the discovery of the thirty-eight spectroscopic binaries with the Mills spectrograph, three had been discovered in the same list of stars by Belopolsky, making forty-one binaries in about 350 stars observed. The proportion is therefore one binary star for every eight observed, not taking into account a considerable list of suspected cases awaiting confirmation. The variable velocity of our Sun, due to its revolving planets, has a double amplitude of only a few hundredths of a kilometer. As the work progresses, and the degree of accuracy attainable increases, we shall probably find that there is a regular gradation of double amplitudes from that of the Sun up to those of the spectroscopic binaries already discovered, and it is possible that the star which is not a spectroscopic binary will prove to be the rare exception.

Acknowledgements are due to Messrs. Wright and Reese for continued efficient assistance in the line of sight work.

July 1,1902 .
W. W. Campbell. 